International Journal of Social Science and Economic Research

ISSN: 2455-8834

Volume:06, Issue:06 "June 2021"

\title{
IMPACT OF COVID - 19 ON VEGETABLE MARKET: A STUDY OF BENGALURU MARKET IN KARNATAKA, INDIA
}

\author{
Dr. Puttaswamaiah S. \\ Associate Professor, Department of Economics, Bangalore University, Bangalore - 560056 \\ DOI: 10.46609/IJSSER.2021.v06i06.003 URL: https://doi.org/10.46609/IJSSER.2021.v06i06.003
}

\begin{abstract}
Pandemic COVID - 19crippled all sectors of economy adversely affecting production and distribution chains along with health of people. Government enforced measures like lockdown accentuatedthe problems, which were more severe in agriculture sector owing to production of perishable products like vegetables, flower and fruits.Large number of farmers could not harvest or market their crop due to lockdown restrictions and supply to market disrupted causing fluctuations in arrival and price, which is more in case of products like vegetables. Considering the adverse impacts of COVID - 19 the present paper examined pattern of arrival, wholesale price and retail price of vegetables in Bangalore vegetable market, by using data available on National Horticulture Board data base. The analysis revealed that during lockdown vegetable supply was completely stopped, and after lockdown supply increased, but with more fluctuations in arrival, indicating adverse impacts of COVID - 19 on production of vegetables. Wholesale price and retail price of vegetables also increased along with rise in supply, which further evidenced price rise during pandemics. This behaviour of market calls for intervention to protect farmers from incurring loss by appropriate measures for harvesting, transporting and marketing of perishable agricultural produce, otherwise which is a national waste.
\end{abstract}

Key Words: COVID - 19, Pandemic, Vegetable market, Bangalore, Market arrival, Retail price

\section{Introduction}

COVID - 19, the pandemic created an unprecedented adverse impacts on people and economy, encompassing the world.High contagiousness and mutation of the Corona virus infected large number of people in first, second wave in several countries, while some countries are facing third wave. Controlling this deadly disease, through medical treatment and containing spread assumed paramount importance in all affected countries, which led to adopting stringent measures like lockdown, social distancing, and hygiene maintenance. Among these, lockdown decision taken by many countries was a bold and significant step, which had severe impacts on their economy.Indian Government, understanding the magnitude and severity of the problem, implemented lockdown on 25 March 2020, where all states had complete lockdown for 37days 


\section{International Journal of Social Science and Economic Research}

ISSN: $2455-8834$

Volume:06, Issue:06 "June 2021"

and in 2021, during second wave, several states clamped lockdown to control spread of the deadly disease. All industries - large scale, MSMEs, IT-BT and commercial establishments closed down their business. Agricultural activities suffered, especially, harvesting and marketing of standing crops like vegetables, fruits, and flowers. News media revealed helpless farmers destroying crops without harvesting due to non-availability of market, labourers and transport facilities.

Various studies across globe observed impacts of lock down on agriculture sector. Lakner S (2020) revealed European Union countries might not face food shortage due to COVID-19, in short run, as large portion of harvesting is conducted in winter, and agriculture depends mainly on machinery and on farm-labour. However, agriculture might suffer in long run owing to delayed or stopped imports of inputs. Further, travel restrictions could reduce supply of seasonal workers hitting cultivation of vegetables, fruits, wine and permanent crops in Italy, Spain, France, and Greece. MSSRF (2020) found world agricultural prices might increase, for rice and wheat owing to stockpiling and export restrictions, adversely affecting food chain and food security. Contrarily price of crops like corn fell in USA due to declined oil prices and transportation of corn for ethanol. The study observed based on USDA data that rice and wheat available in inventories would be sufficient normally for 2 months, and problems arise if lockdown continues beyond. Agriculture across USA, European Union and Australia would face severe labour shortage in the absence of seasonal migrant labourers. With respect to India the study observed that the overall food articles supply was not worrisome due to available stock and production of wheat, rice, milk and other products. But, continued lockdown would disrupt supply chain increasing price. Harvesting and marketing of crops at farm adversely affected due to disruptions in procurement, transportation, APMC functioning, non-availability of labourers, resulting price crash, particularly for vegetables, fruits and flowers in several states. However, persisting lockdown would increase the prices as observed by the study. Dev Mahendra S (2020) stated that COVID-19 disrupted agricultural activities, particularly harvesting wheat and pulses in north-west India. Transportation problem crippled supply chain of some produce. Further, price of wheat, vegetables, etc. fell due to non-clearance at farm, while consumers were paying more.Kaur Gurneel (2020) reported adverse effects of Corona virus induced lockdown on agriculture sector, especially harvesting of standing crops like wheat, mustard and pulses. Restrictions of lockdown kept away labourers and machines from field.

COVID-19 lockdown affected economy badly in India and also across the world. All sectors of the economy suffered resulting in reduced or stopped production and increasing unemployment. Review of literature indicated that agriculture sector faced problems particularly in short gestation cash crops like vegetables, fruits and flowers. Large number of farmers could not harvest or market their crop produces due to lockdown incurring loss. As the adverse impact was 
International Journal of Social Science and Economic Research

ISSN: 2455-8834

Volume:06, Issue:06 "June 2021"

more on short gestation, perishable cash crops like vegetables, an analysis of market arrival and price during the pandemic period would throw light on vegetable market behaviour. In this background the present paper attempts to examine pattern of arrival, wholesale price and retail price of vegetables in market. Data on arrival, wholesale price and retail price were collected from National Horticulture Board (Website - nhb.gov.in), which provides information on monthly basis. This study collected information for year 2019 and 2020 for examining impacts of COVID - 19 on behaviour of vegetable market. It is to be noted that 2019 is a no COVID - 19 year, while 2020 suffered the onslaught of COVID -19, hence provide a comparative picture of impacts. The study focused on Bangalore vegetable market in Karnataka as data are available from National Horticulture Board. Data have been analysed on monthly basis for understanding impacts of COVID - 19, by applying statistical tools like coefficient of variation, growth rate and index numbers for identifying fluctuations in vegetable market. This analysis would reveal impacts of COVID - 19 on vegetable market of Bangalore in Karnataka.

\section{Discussion of Results}

\subsection{Impact of COVID - 19 on vegetable arrival to Bangalore Market}

Spread of COVID - 19 and implementation of lockdown for controlling the diseases adversely affected every economic activity like production, marketing due to restrictions on movement of people and goods. Although, transport of goods was relaxed for certain types of items, fear of contacting the disease and strict implementation of rules curtailed movement of commodities, such as vegetables. In this respect, an analysis of arrival of vegetables to market would be appropriate to understand impacts COVID - 19. Arrival of vegetables to Bangalore market during January to December 2020 has been presented in Table 1, which shows information on vegetables like bitter guard, cabbage, cauliflower, ginger, okra (lady finger), onion, potato and tomato. It can be noticed that arrival of all vegetables to market increased between January and December. For instance, quantity of bitter guard arrived to Bangalore market was over 80 metric tonnes in January 2020, and increased to 171 metric tonnes in December, 2020. Similarly, supply of all vegetablesincreased by two fold during this period. Among several vegetables, onion and potato arrived in larger quantity as compared to other vegetables. Next to onion and potato, cabbage, tomato, okra and other vegetables supplied in higher quantity. However, in April and May, 2020 Bangalore market did not receive any vegetable due to COVID - 19 induced lockdown. Non - arrival of vegetables indicates that large number of farmers might not have harvested vegetables during these months as they could not sell in market due to transport restrictions. Further, arrival of vegetables fluctuated across months in 2020 revealing adverse effects on supply to market. 
International Journal of Social Science and Economic Research

ISSN: 2455-8834

Volume:06, Issue:06 "June 2021"

Table 1: Arrival of vegetables in Bangalore Market during 2020 (in metric tonnes)

\begin{tabular}{|c|c|c|c|c|c|c|c|c|}
\hline Months & $\begin{array}{c}\text { Bitte } \\
\text { r } \\
\text { guar } \\
\text { d }\end{array}$ & $\begin{array}{c}\text { Cabbag } \\
\mathrm{e}\end{array}$ & $\begin{array}{c}\text { Cauliflo } \\
\text { wer }\end{array}$ & Ginger & Okra & Onion & Potato & $\begin{array}{l}\text { Tomato } \\
\text { Hybrid }\end{array}$ \\
\hline January & 82 & 816 & 102 & 226 & 226 & 39474 & 18504 & 795 \\
\hline February & 101 & 759 & 79 & 228 & 228 & 44473 & 17023 & 773 \\
\hline March & 75 & 864 & 69 & 183 & 183 & 46386 & 13297 & 687 \\
\hline April & 0 & 0 & 0 & 0 & 0 & 0 & 0 & $\overline{0}$ \\
\hline May & 0 & 0 & 0 & 0 & 0 & 0 & 0 & 0 \\
\hline June & 124 & 1076 & 240 & 395 & 925 & 45336 & 18400 & 1433 \\
\hline July & 32 & 271 & 53 & 141 & 272 & 14927 & 4272 & 409 \\
\hline August & 79 & 1305 & 161 & 336 & 306 & 28572 & 16237 & 545 \\
\hline September & 150 & 987 & 151 & 475 & 306 & 51773 & 17938 & 942 \\
\hline October & 156 & 1244 & 180 & 483 & 465 & 58800 & 28174 & 1474 \\
\hline November & 135 & 1242 & 180 & 358 & 434 & 45386 & 18038 & 1348 \\
\hline December & 171 & 1872 & 271 & 405 & 531 & 51195 & 24685 & 1520 \\
\hline
\end{tabular}

Source: National Horticulture Board - Website

Note: No arrival to market in April and May

Impact of COVID -19 on vegetable arrival to Bangalore market can be seen by examining difference in quantity of vegetables arrived during 2020 and 2019. Table 2 illustrates the difference in vegetable arrived to Bangalore market. Values with negative (-) sign indicate decline in quantity of vegetables arrived in the year 2020 as compared to 2019. It can be observed that vegetable supplied to Bangalore market declined in January and February 2020 as compared to January and February of 2019. Due to lockdown in April and May 2020 there was no supply of vegetables to market. The lockdown was opened in May 2020 and hence more quantity of vegetables were supplied in June 2020. But, in July and August 2020 vegetable supplied was less than that in same of months of 2019. It shows that farmers might not have cultivated vegetables during lockdown periodand hence supply got reduced. Therefore, COVID - 19 induced lock down has adversely affected production of several vegetables till August 2020. Supply of vegetables increased from September, 2020 onwards for several vegetables compared to same period in 2019, excepting onion and potato, as arrival of potato was less in 2020. 
International Journal of Social Science and Economic Research

ISSN: 2455-8834

Volume:06, Issue:06 "June 2021"

Table 2: Difference in arrival of vegetables between 2020 and 2019

\begin{tabular}{|l|r|r|r|r|r|r|r|r|}
\hline \multicolumn{1}{|c|}{ Months } & $\begin{array}{r}\text { Bitter } \\
\text { guard }\end{array}$ & Cabbage & Cauliflower & Ginger & Okra & Onion & Potato & $\begin{array}{r}\text { Tomato } \\
\text { Hybrid }\end{array}$ \\
\hline January & -50 & -171 & -12 & -133 & -72 & -21889 & -7892 & -172 \\
\hline February & -8 & -519 & -34 & -208 & -96 & -5751 & -6794 & -418 \\
\hline March & -19 & 12 & -37 & -64 & -32 & -7006 & -8733 & -312 \\
\hline April & 88.5 & -871 & -83 & -200 & -204 & 48478 & 25178 & -865 \\
\hline May & -83 & -858 & -88 & -216 & -251 & 45229 & 21469 & -899 \\
\hline June & 27 & 115 & 149 & 86 & 690 & -2241 & -9043 & 513 \\
\hline July & -81 & -863 & -62 & -164 & -63 & -379 & 25437 & -671 \\
\hline August & -21 & 366 & 66 & 69 & 35 & 23193 & 14333 & -423 \\
\hline September & 60 & 65 & 55 & 152 & 66 & 11415 & 11940 & -25 \\
\hline October & 53 & 307 & 65 & 151 & 211 & 80406 & -5332 & 238 \\
\hline November & 40 & 265 & 87 & 52 & 202 & -5753 & -9285 & 317 \\
\hline December & 50 & 745 & 164 & 102 & 224 & 895 & -1264 & 436 \\
\hline
\end{tabular}

Source: Author calculation based on data from National Horticulture Board

Note: negative sign (-) indicates decline in arrival during 2020

Impact of COVID - 19 on vegetable arrival to market could be understood by examining variations in supply and growth rate during 2019 and 2020. Table 3 illustrates coefficient of variation and growth rate of quantity of vegetables arrived to Bangalore market during 2019 and 2020. Coefficient of variation depicts fluctuations in vegetables arrived to market, while growth rate shows increase or decrease of arrival. Arrival of vegetables to Bangalore market fluctuated to a higher extent for all vegetables as the coefficient of variation varied from 51 per cent for ginger to 81 per cent for onion during 2020. Highest variation in market arrival was observed for onion followed by cabbage ( 80 per cent), and okra (lady fingers -69 per cent). Arrival of all vegetables fluctuated with more than 50 per cent indicating the adverse impact of COVID - 19 on vegetable supply. Further, the fluctuation in 2020 was higher than that in 2019 as arrival of all vegetables showed coefficient of variation in the range of 11.13 per cent (Tomato hybrid) to 21.2 
per cent (Ginger), excepting onion with 44 per cent. It reveals that COVID - 19 has brought instability in the supply of vegetables to markets. Arrival of all vegetables experienced growth rate of around one per cent during both 2019 and 2020, indicating no decline.

\begin{tabular}{|l|r|r|r|r|}
\hline \multicolumn{5}{|c|}{ Table 3: Fluctuations and growth rate in arrival of vegetables } \\
\hline \multirow{2}{*}{ Vegetables } & \multicolumn{2}{|c|}{2019} & \multicolumn{2}{|c|}{2020} \\
\cline { 2 - 5 } & $\begin{array}{c}\text { Coefficient } \\
\text { of variation }\end{array}$ & $\begin{array}{c}\text { Compound } \\
\text { Growth rate }\end{array}$ & $\begin{array}{r}\text { Coefficient } \\
\text { of variation }\end{array}$ & $\begin{array}{r}\text { Compound } \\
\text { Growth rate }\end{array}$ \\
\hline Bitter guard & 14.04 & 1 & 55.73 & 1.04 \\
\hline Cabbage & 13.11 & 1 & 79.92 & 1.1 \\
\hline Cauliflower & 11.46 & 1 & 52.08 & 1.06 \\
\hline Ginger & 21.22 & 1 & 51.43 & 0.98 \\
\hline Okra & 16.32 & 1 & 69.19 & 1.06 \\
\hline Onion & 44.36 & 1.05 & 81.35 & 1.09 \\
\hline Potato & 13.3 & 1.02 & 54.77 & 1.08 \\
\hline $\begin{array}{l}\text { Tomato } \\
\text { Hybrid }\end{array}$ & 11.13 & 1.01 & 60.4 & 1.06 \\
\hline
\end{tabular}

Source: Author calculation based on data from National Horticulture Board

\subsection{Impact of COVID - 19 on wholesale price of vegetables in Bangalore Market}

Pattern of wholesale price of vegetables in Bangalore market has been presented to examine behaviour of price during COVID -19 period in 2020. Table 4 illustrates wholesale price of different vegetables in Bangalore market during various of months of 2020. The wholesale price reveals a mixed picture in price variations during 2020 as price of few vegetables increased while for few decreased and some vegetables experienced not much change in price during the period. Wholesale price of bitter guard, cauliflower and potato increased, while that of cabbage, ginger and onion decreased between January and December 2020. Further, it can be observed that in February and March wholesale price decreased. After opening of lockdown wholesale price increased significantly for vegetables like bitter guard andginger, but for cabbage and onion it declined. During the post lockdown period the wholesale price has fluctuated to a larger extent for all vegetables. 
International Journal of Social Science and Economic Research

ISSN: 2455-8834

Volume:06, Issue:06 "June 2021"

Table 4: Wholesale price of vegetables in Bangalore market in 2020

(Rupees per quintal)

\begin{tabular}{|l|r|r|r|r|r|r|r|r|}
\hline Months & $\begin{array}{l}\text { Bitter } \\
\text { guard }\end{array}$ & Cabbage & Cauliflower & Ginger & Okra & Onion & Potato & $\begin{array}{c}\text { Tomato } \\
\text { Hybrid }\end{array}$ \\
\hline January & 2438 & 1170 & 1553 & 3860 & 2090 & 3280 & 2125 & 1550 \\
\hline February & 1784 & 671 & 1426 & 3474 & 1442 & 1966 & 1713 & 1197 \\
\hline March & 1159 & 500 & 1156 & 3063 & 1488 & 1494 & 1506 & 838 \\
\hline April & 0 & 0 & 0 & 0 & 0 & 0 & 0 & 0 \\
\hline May & 0 & 0 & 0 & 0 & 0 & 0 & 0 & 0 \\
\hline June & 3154 & 840 & 1558 & 4290 & 1446 & 850 & 1912 & 1540 \\
\hline July & 3356 & 844 & 1294 & 4938 & 913 & 825 & 2281 & 2381 \\
\hline August & 3216 & 791 & 1619 & 4313 & 2378 & 1250 & 2259 & 1809 \\
\hline September & 2981 & 1488 & 1865 & 4625 & 4148 & 2360 & 2723 & 3083 \\
\hline October & 3090 & 2716 & 1984 & 3428 & 3368 & 4719 & 3177 & 2274 \\
\hline November & 2048 & 2221 & 1779 & 3167 & 1650 & 5062 & 3417 & 1888 \\
\hline December & 2617 & 879 & 2358 & 2623 & 2023 & 2869 & 2888 & 1575 \\
\hline
\end{tabular}

Source: National Horticulture Board - Website

Let us understand variations in wholesale price of vegetables in Bangalore market between 2019 and 2020 by examining coefficient of variation, presented in Fig. 1. Wholesale price did not fluctuate much in 2019 for large number of vegetables, except onion. Potato experienced less fluctuation in wholesale price, 16 per cent, while it was 32 per cent for bitter guard. It can be observed that onion observed high variations in its wholesale price at 106 per cent. The market experienced high fluctuation in wholesale price of vegetables during 2020. The coefficient of variation ranges from 19 per cent for ginger to 61 per cent for onion. Other vegetables like cabbage, okra showed higher variation of 59 and 47 per cent respectively. The wholesale price of vegetables fluctuated more in 2020 as compared to that in 2019 indicating impact of COVID 19. Variation in wholesale price in 2020 may be attributed to fluctuations in supply of vegetables to Bangalore market. 
International Journal of Social Science and Economic Research

ISSN: 2455-8834

Volume:06, Issue:06 "June 2021"

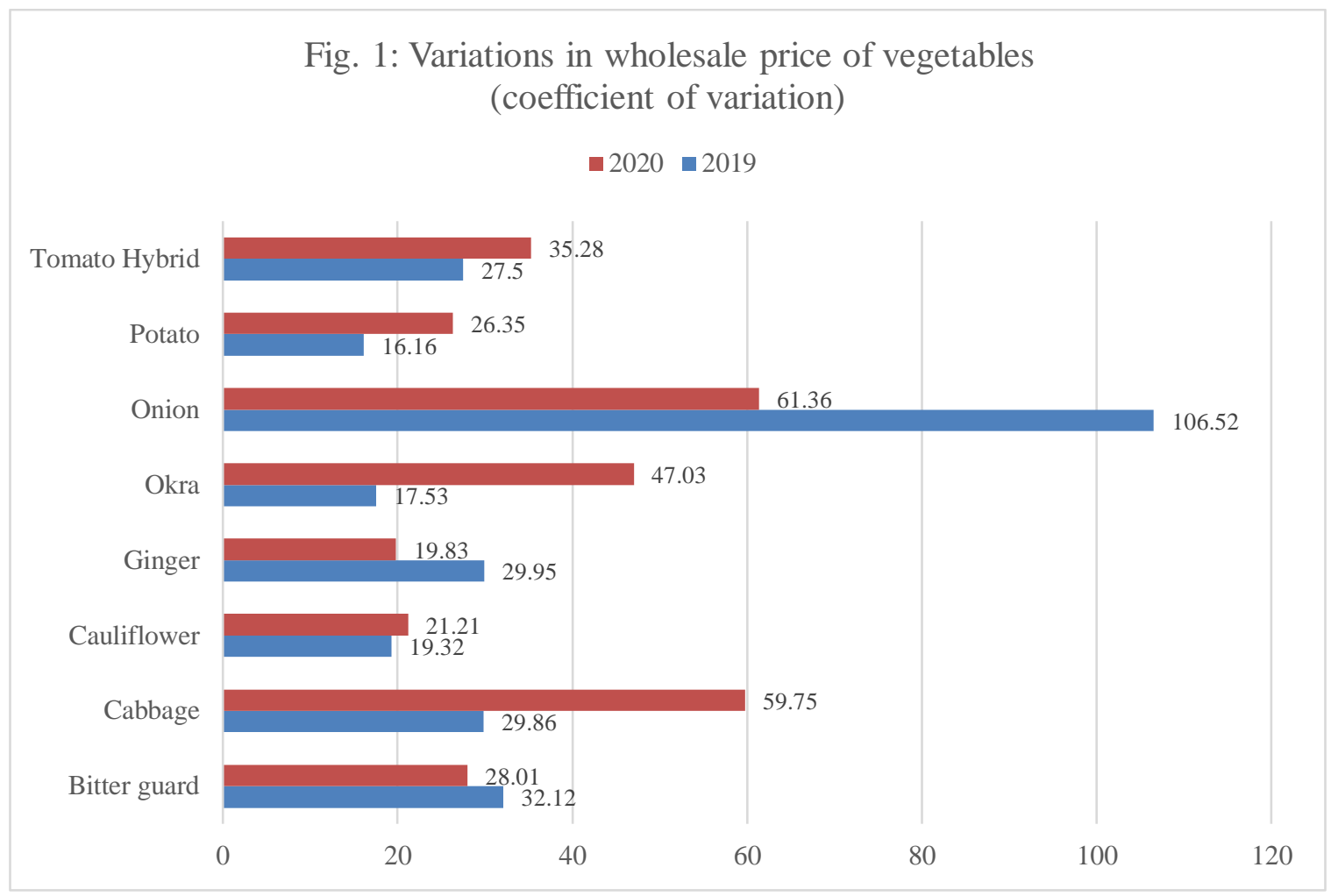

\subsection{Impact of COVID - 19 on retail price of vegetables in Bangalore Market}

As observed above supply of vegetables fluctuated to a large extent during COVID - 19 in the year 2020. Impact of this can be seen by examining retail price, the price which consumers pay while purchasing vegetables from sellers. Whenever, supply varies in market the price also fluctuates and usually increases during uncertain times like that of pandemic. Retail price of vegetables in Bangalore market for the year 2020, Table 5, revealed an increase in price of some vegetables after lockdown period, particularly between June and September. Price of bitter guard, cabbage, cauliflower, okra, onion, potato and tomato increased during these months. For instance, bitter guard price increased to Rs. 5938 per quintal in July from Rs. 4890 per quintal in January 2020. This shows that COVID - 19 induced lockdown affected supply of vegetables and hence price increased during the said period.

Table 5: Retail price of vegetables in Bangalore market in 2020

(Price - Rupees per quintal)

\begin{tabular}{|l|r|r|r|r|r|r|r|r|}
\hline Months & $\begin{array}{c}\text { Bitter } \\
\text { guard }\end{array}$ & $\begin{array}{c}\text { Cabba } \\
\text { ge }\end{array}$ & $\begin{array}{c}\text { Caulif } \\
\text { lower }\end{array}$ & $\begin{array}{c}\text { Ginge } \\
\mathrm{r}\end{array}$ & Okra & Onion & Potato & $\begin{array}{c}\text { Tomat } \\
\text { o } \\
\text { Hybrid }\end{array}$ \\
\hline January & 4890 & 2345 & 3100 & 8175 & 3800 & 5500 & 3550 & 2535 \\
\hline
\end{tabular}


International Journal of Social Science and Economic Research

ISSN: 2455-8834

Volume:06, Issue:06 "June 2021"

\begin{tabular}{|l|r|r|r|r|r|r|r|r|} 
February & 3921 & 1537 & 3016 & 7737 & 3132 & 3384 & 3179 & 2084 \\
\hline March & 2750 & 1944 & 2375 & 6375 & 2969 & 2638 & 2750 & 1431 \\
\hline April & 0 & 0 & 0 & 0 & 0 & 0 & 0 & 0 \\
\hline May & 0 & 0 & 0 & 0 & 0 & 0 & 0 & 0 \\
\hline June & 5480 & 2080 & 2940 & 7420 & 2588 & 1436 & 3060 & 2532 \\
\hline July & 5938 & 1588 & 2763 & 7938 & 2000 & 1400 & 3813 & 3563 \\
\hline August & 5594 & 1525 & 3144 & 7594 & 4250 & 2094 & 3813 & 2925 \\
\hline September & 5417 & 2467 & 3425 & 8146 & 6083 & 3713 & 4388 & 4600 \\
& & & & & & & & \\
\hline October & 5660 & 4060 & 3672 & 5940 & 5340 & 6463 & 4833 & 3516 \\
\hline November & 4405 & 3676 & 3448 & 5476 & 3143 & 6976 & 5048 & 3019 \\
\hline December & 4769 & 1773 & 4454 & 4808 & 3423 & 5827 & 4496 & 2619 \\
\hline
\end{tabular}

Source: National Horticulture Board - Website

In order to know variations retail price index has been constructed and presented in Table 6, with January 2020 as base.Retail price of several vegetables increased since August 2020 in comparison with the price of January indicating the impact of COVID - 19. It is to be noted that arrival of vegetables during these months did not decline as observed earlier, but, still retail price has increased. Price increased for almost all vegetables during September, October and November 2020, though market arrival increased during these months. This increase in retail price of vegetables might indicate traders behaviour of earning higher profits during difficult or uncertain periods like pandemic.In other words, COVID - 19 induced effects caused rise in vegetables price.

\begin{tabular}{|l|r|r|r|r|r|r|r|r|}
\hline \multicolumn{7}{|c|}{ Table 5: Retail price index of vegetables in 2020 } \\
\hline Months & $\begin{array}{l}\text { Bitter } \\
\text { guard }\end{array}$ & $\begin{array}{c}\text { Cabbag } \\
\mathrm{e}\end{array}$ & $\begin{array}{c}\text { Caulifl } \\
\text { ower }\end{array}$ & Ginger & Okra & Onion & Potato & $\begin{array}{c}\text { Tomato } \\
\text { Hybrid }\end{array}$ \\
\hline January & 100.00 & 100.00 & 100.00 & 100.00 & 100.00 & 100.00 & 100.00 & 100.00 \\
\hline February & 80.18 & 65.54 & 97.29 & 94.64 & 82.42 & 61.53 & 89.55 & 82.21 \\
\hline March & 56.24 & 82.90 & 76.61 & 77.98 & 78.13 & 47.96 & 77.46 & 56.45 \\
\hline April & 0.00 & 0.00 & 0.00 & 0.00 & 0.00 & 0.00 & 0.00 & 0.00 \\
\hline May & 0.00 & 0.00 & 0.00 & 0.00 & 0.00 & 0.00 & 0.00 & 0.00 \\
\hline June & 112.07 & 88.70 & 94.84 & 90.76 & 68.11 & 26.11 & 86.20 & 99.88 \\
\hline July & 121.43 & 67.72 & 89.13 & 97.10 & 52.63 & 25.45 & 107.41 & 140.55 \\
\hline August & 114.40 & 65.03 & 101.42 & 92.89 & 111.84 & 38.07 & 107.41 & 115.38 \\
\hline $\begin{array}{l}\text { Septembe } \\
\text { r }\end{array}$ & 110.78 & 105.20 & 110.48 & 99.65 & 160.08 & 67.51 & 123.61 & 181.46 \\
\hline
\end{tabular}


International Journal of Social Science and Economic Research

ISSN: 2455-8834

Volume:06, Issue:06 "June 2021"

\begin{tabular}{|l|r|r|r|r|r|r|r|r|}
\hline October & 115.75 & 173.13 & 118.45 & 72.66 & 140.53 & 117.51 & 136.14 & 138.70 \\
\hline $\begin{array}{l}\text { Novembe } \\
\mathrm{r}\end{array}$ & 90.08 & 156.76 & 111.23 & 66.98 & 82.71 & 126.84 & 142.20 & 119.09 \\
\hline $\begin{array}{l}\text { Decembe } \\
\mathrm{r}\end{array}$ & 97.53 & 75.61 & 143.68 & 58.81 & 90.08 & 105.95 & 126.65 & 103.31 \\
\hline
\end{tabular}

Source: Author calculation based on data from National Horticulture Board

Note: January 2020 considered as base

Above discussion revealed variations in retail price across months in 2020. Further, in order to compare fluctuations in retail price of vegetables coefficient of variation was calculated for 2019 and 2020 (Fig. 2). The retail price of almost all vegetables remained stable in 2019, except

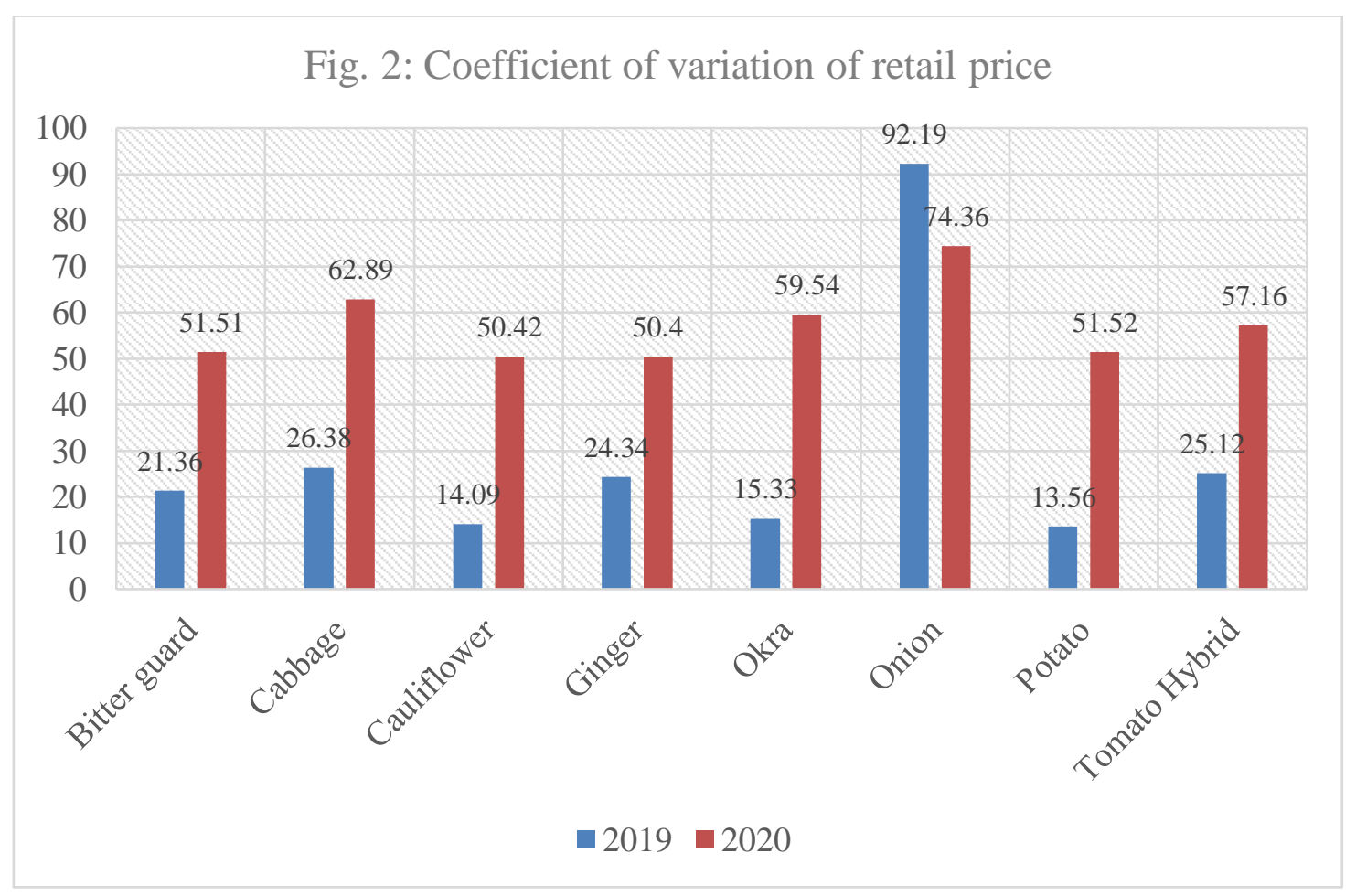

onion, and the variation was between 13.56 for potato and 26.38 for cabbage. Coefficient of variation of retail price of onion was high (92) indicating more fluctuation. Apart from onion, cabbage, ginger and tomato experienced price fluctuation. Vegetables price fluctuated more in 2020 as compared to that in 2019 as the coefficient of variation of all vegetables remained over 50 , i.e. in the range of 51 and 92 . It indicates more fluctuation in retail price of vegetables during pandemic period, reflecting adverse impacts of COVID - 19. 


\section{International Journal of Social Science and Economic Research}

ISSN: $2455-8834$

Volume:06, Issue:06 "June 2021"

\section{Conclusion}

Spread of COVID - 19 crippled all economic activities across the globe, resulting hardships to people. Lockdown implemented as a major weapon to control the pandemic made economies to incur huge loss due to disturbance in production and distribution chains. Agriculture sector also experienced problems like farmers unable to harvest and market their crop. Analysis of arrival and prices of vegetables in Bangalore market revealed several observations on impacts of COVID - 19. During 2020 vegetable arrival to market fluctuated across months, while two months, i.e. April and May, not receiving supply. Arrival of vegetables reduced in July and August showing the impact of lockdown on vegetable cultivation, but, towards end of the year vegetable supply increased as compared to 2019. The supply varied across months for all vegetables, which showed fluctuations in production of vegetable by farmers. Similarly, wholesale price of vegetables also fluctuated more during this period, where some vegetables observed price rise and others decline. Retail price increased for more number of vegetables during pandemic time. Considering the adverse impacts of pandemic on vegetable markets necessary measures such as removing restrictions on vegetable harvesting, transporting and marketing need to be implemented to protect farmers from incurring loss. Besides, it would ensure availability of vegetables to consumers thus safeguarding interest of farmers and people.

\section{Acknowledgement}

The present research paper has not availed grant from any source.

\section{References}

Dev Mahendra S (2020), Addressing COVID-19 impacts on agriculture, food security, and livelihoods in India, Available at - https://www.ifpri.org/blog/addressing-covid-19impacts-agriculture-food-security-and-livelihoods-india

Kaur Gurneel (2020), Coronavirus lockdown having an adverse effect on agriculture sector in India, Available at - https://www.grainmart.in/news/coronavirus-lockdown-having-anadverse-effect-on-agriculture-sector-in-india/

Lakner S (2020), Effects of Coronavirus on Agricultural Production - a First Approximation (part 2), Available at- https://www.arc2020.eu/effects-of-coronavirus-on-agriculturalproduction-a-first-approximation-part-2/

MSSRF (M. S. Swaminathan Research Foundation 2020), The Covid-19 Pandemic and Indian Agriculture: A Note, Available at - https://www.mssrf.org/content/covid\%C2\%AD-19pandemic-and-indian-agriculture-note 
International Journal of Social Science and Economic Research

ISSN: 2455-8834

Volume:06, Issue:06 "June 2021"

National Horticulture Board, Ministry of Agriculture \& Farmers Welfare, Government of India, (Website

http://nhb.gov.in/OnlineClient/Monthwise AnnualPriceandArrivalReport.aspx?enc=3ZOO 8K5CzcdC/Yq6HcdIxJ4o5jmAcGG5QGUXX3BlAP4=) 